\title{
Motif Wisatawan Mengunjungi Masjid Agung Madani Islamic Centre (Mamic) Pasir Pangaraian Kabupaten Rokan Hulu
}

\author{
Ayu Wulandari', Erianjoni Erianjoni ${ }^{2}$ \\ ${ }^{1,2}$ Universitas Negeri Padang \\ email: wulandariayu852@gmail.com
}

\begin{abstract}
Abstrak
Penelitian ini dilatarbelakangi oleh ketertarikan peneliti dalam melihat banyaknya wisatawan yang mengunjungi Masjid Agung Madani Islamic Centre (MAMIC). Tujuan penelitian ini adalah untuk mengetahui motif wisatawan mengunjungi Masjid Agung Madani Islamic Centre. Hasil temuan dianalisis dengan menggunakan Teori Fenomenologi dari Alfred Schutz yang memahami mengenai tindakan sosial. Penelitian ini menggunakan pendekatan kualitatif dengan tipe penelitian fenomenologi.Hasil penelitian ini mengungkapkan bahwa ada dua yang menjadi motif wisatawan mengunjungi Masjid Agung Madani Islamic Centre (MAMIC) adalah; (1) Motif Internal terdiri atas a.) Pergi berwisata dan jalan-jalan b.) Melihat desain MAMIC. (2) Motif Ekternal terdiri atas a.) Informasi ataupun dorongan dari teman b.) Melihat iklan dan spanduk c.) Informasi dari Internet dan media sosial.
\end{abstract}

Kata Kunci: Motif, Wisatawan, MAMIC

\section{Abstract}

This research is motivated by the interest of researchers in seeing the number of tourists visiting the Masjid Agung Madani Islamic Centre (MAMIC). The purpose of this study to determine the motives of tourists visiting the Masjid Agung Madani Islamic Centre (MAMIC). The findings were analyzed by Alfred Schutz's Theory of Phenomenologywho also understood social action. This research uses qualitatif approach with phenomenological researh type. The results of this study reveal that there are two that are the motives of tourists visiting Masjid Agung Madani Islamic Centre (MAMIC) is; (1) Internal motives consist of a.) Go on tours and sightseeing b.) Look at the design MAMIC (2) External motives consist of a.) Information oe encouragement from friends b.) See advertisements and banners $c$.) Information from the internet and social media,

Key Word: Motive, Tourist, MAMIC 


\section{Pendahuluan}

Indonesia sebagai salah satu negara yang besar dan memiliki keanekaragaman budaya dan juga agama yang dianut oleh rakyatnya, tentu memiliki banyak daya tarik wisata religi yang tersebar di seluruh penjuru Indonesia. Salah satu provinsi yang memiliki daya tarik wisata religi yang cukup banyak adalah provinsi Riau. Sebagai salah satu provinsi di Indonesia, Riau mempunyai banyak daya tarik termasuk wisata religi seperti Masjid Agung An-Nur, makam Raja-raja Rambah, Haul Tuan Guru Sapat, Masjid Agung Madani Islamic Centre, Makam Syekh Abdurrahman Siddiq dan masih banyak lagi. Dari beberapa yang telah disebutkan di atas, yang akan dibahas dalam penelitian ini adalah Masjid Agung Madani Islamic Centre yang terdapat di Pasir Pangaraian, Rokan Hulu yang merupakan salah satu masjid terbesar dan termegah yang ada di Riau.

Masjid merupakan bangunan tempat shalat kaum muslimin yang digambarkan sebagai bangunan besar tempat shalat berjamaah dengan berbagai atribut kemasjidannya. Masjid adalah sebuah bangunan tempat ibadah (shalat) yang bentuk bangunannya dirancang khusus dengan berbagi atribut masjid seperti ada menara yang cukup megah sebagai kebanggaan masing-masing, kubah dan lain-lain. ${ }^{1}$ Masjid adalah rumah Allah yang dibangun sebagai sarana bagi umat Islam untuk mengingat, mensyukuri dan menyembah Allah SWT dengan baik. Selain itu tempat melaksanakan berbagai aktivitas amal saleh, seperti tempat bermusyawarah, pernikahan, mencari solusi permasalahan yang trjadi di tengah-tengah umat dan sebagainya. tempat ibadah Masjid tidak hanya sebagai pusat ibadah, akan tetapi juga sebagai pusat aktivitas sosial. Masjid adalah tempat bertemunya berbagai segmen masyarakat, baik di masa dahulu maupun sekarang. Sebagai wahana bertemunya warga masyarakat yang berkepentingan untuk melakukan ibadah, maka masjid juga menjadi tempat untuk silaturrahmi. Selain itu juga menjadi tempat untuk mengembangkan pengetahuan agama dan sosial kemasyarakatan.

Bupati Rokan Hulu dua periode 2006-2016, Drs. H Achmad, M.Si membuat kebijakan mendirikan satu masjid sebagai simbol dan pusat pembinaan umat tingkat Kabupaten Rokan Hulu. Masjid megah ini diberi nama Masjid Agung Madani Islamic Centre Pasir Pangaraian Kabupaten Rokan Hulu atau yang biasa disingkat dengan MAMIC yang dibangun pda tanggal 29 Desember 2008. Masjid Agung Madani Islamic Centre Pasir Pangaraian Rokan Hulu ditetapkan sebagai masjid agung percontohan juara 1 tingkat nasional oleh Kementerian Agama Republik Indonesia Nomor: 01/DPM.MA/XI/2015 tentang Penetapan Masjid Agung Percontohan Tingkat Nasional.

Setelah ditetapkan menjadi masjid agung percontohan, masjid ini diberi nama Masjid Agung Madani Nasional Islamic Centre Pasir Pangaraian Kabupaten Rokan Hulu berdasarkan Peraturan Bupati Rokan Hulu Nomor 12 tahun 2016 tentang pembentukan Badan Pengelola Masjid Agung Madani Nasional Islamic Centre Pasir Pangaraian Kabupaten Rokan Hulu. Meski masjid ini merupakan masjid yang tergolong baru di Kabupaten Rokan Hulu maupun Provinsi Riau, namun masjid ini telah berhasil menunjukan keunggulannya sehingga sekarang menjadi objek wisata religi yang unggul dan merupakan ikon dari Kabupaten Rokan Hulu.

Dari banyaknya potensi wisata yang dimiki Kabupaten Rokan Hulu, penulis tertarik menjadikan Masjid Agung Madani Islamic Centre ini sebagai objek penelitian sebab objek ini masih tergolong baru namun sudah mampu menarik begitu banyak pengunjung. Setiap harinya ramai di kunjungi wisatawan baik dalam negeri seperti Sumatera Barat, Sumatera

\footnotetext{
${ }^{1}$ Suherman, Eman. 2012. Manajemen Masjid: Kiat Sukses Meningkatkan kualitas Sumber Daya Manusia melalui Optimalisasi Kegiatan Umat Berbasis Pendidikan Berkualitas Unggul. Bandung: CV. Alfabeta. 
Utara, Lampung, Jambi, Pekanbaru, dan kota-kota lain di Riau serta juga ada dari luar negeri seperti Malaysia, Brunei Darussalam dan Negara Timur Tengah.

Berdasarkan kenyataan tersebut dapat dilihat bahwa dari tahun ketahun jumlah wisatawan yang mengunjungi Masjid Agung Madani Islamic Centre (MAMIC) mengalami peningkatan secara signifikan. Kunjungan wisatawan ini tentu dilatarbelakangi oleh sesuatu hal. Hal tersebut biasanya disebut dengan motif. Motif adalah keadaan dalam diri pribadi seseorang yang mendorong individu untuk melakukan aktivitas-aktivitas tertentu guna mencapai suatu tujuan. ${ }^{2}$ Rasa ingin tahu terhadap motif inilah yang membuat peneliti ingin melakukan penelitian secara mendalam.

Penelitian ini dianalisis dengan menggunakan Teori Fenomenologi yang dikemukakan oleh Alfred Schutz dimana motif dapat dilihat dari dua aspek, yaitu because order to motive dan in order to motive.

\section{Metode Penelitian}

Penelitian ini dilakukan di Masjid Agung Madani Islamic Centre (MAMIC) Pasir Pangaraian Kabupaten Rokan Hulu. Masjid ini dipilih karena merupakan satu-satunya masjid selain digunakan sebagai tempat ibadah juga digunakan untuk pengembangan IMTAQ dan IPTEK dan dijadikan sebagai kawasan wisata religi, bahkan menjadi icon Kabupaten Rokan Hulu, Selain itu, Masjid ini juga dipilih karena terjadinya peningkatan pengunjung yang mengunjungi kawasan MAMIC 5 tahun terakhir yaitu dari tahun 2013- awal tahun 2018. Dilihat dari pendekatannya, penelitian ini termasuk kualitatif dengan tipe fenomenologi. Pemilhan informan dilakukan secara purposive sampling. Data dikumpulkan melalui wawancara, observasi, dan studi dokumentasi. Agar data yang diperoleh bisa dipercaya, maka dalam penelitian ini dilakukan triangulasi data.

Kemudian data yang diperoleh dianalisis dengan menggunakan analisis interaktif oleh Milles dan Huberman dengan langkah mengumpulkan data, reduksi data, display data, dan menarik kesimpulan/verifikasi. Dimana aktivitas dalam analisis data ini dilakukan secara terus menerus pada setiap tahap penelitian sampai penelitian ini selesai.

\section{Motif Wisatawan Mengunjungi Masjid Agung Madani Islamic Centre (MAMIC)}

Masjid Agung Madani Islamic Centre (MAMIC) merupakan masjid yang pendiriannya dilatar belakangi karena belum adanya masjid representatif untuk dijadikan tempat shalat dan kegiatan keagamaan setingkat kabupaten, satu masjid yang dapat dijadikan sebagai pusat aktifitas sekaligus simbol umat islam di Rokan Hulu, apalagi daerah ini dijuluki Negeri Seribu Suluk. Masjid yang dibangun pada tahun 2008 ini telah dinobatkan sebagai masjid paripurna Nomor 1 se-Indonesia pada tahun 2015 dan mengalami peningkatan jumlah kunjungan ke MAMIC dari tahun ketahun secara signifikan. Berdasarkan wawancara dengan Oktari selaku Kabag Humas Informasi, Dokumentasi, Pelayanan dan Pemandu diperoleh data yang menunjukan jumlah kunjungan wisatawan ke MAMIC dalam kurun waktu 5 tahun terakhir ini, baik wisatawan lokal maupun wisatawan mancannegara.

Penelitian ini dilakukan untuk memperoleh jawaban dari pertanyaan penelitian yaitu apa yang menjdai motif wisatawan mengunjungi masjid agung madani islamic centre. Hasil peneitian ini menunjukkan bahwa ada beberapa motif yang mempengaruhi pertambahan jumlah kunjungan ke masjid agung madani islamic center. Terjadinya peningkatan jumlah pengunjung yang sangat signifikan ke Masjid Agung Madani Islamic Centre baik itu pengunjung di daerah rokan hulu sendiri, luar rokan hulu bahkan tidak sedikit pengunjung dari luar Indonesia. Menurut Alfred Schutz, tindakan atau perilaku seseorang dipengaruhi

${ }^{2}$ Sumadi Suryabrata. Psikologi Pendidikan. (Jakarta: Rajawali Pers, 2012), hal 70 
oleh 2 motif, yang pertama adalah motif yang berasal dari dalam diri seseorang (in order to motive) dan motif yang disebabkan oleh faktor di luar diri seseorang (because order to motive). Adapun motif wisatawan mengunjungi Masjid Agung Madani Islamic Centre dalam penelitian ini dipaparkan berdasarkan hasil penelitian berikut ini:

\section{Pergi Berekeasi dan Jalan-Jalan}

Rekreasi adalah suatu kegiatan yang dilakukan untuk penyegaran jasmani dan rohani seseorng. Kegiatan umum yang sering dilakukan adalah berwisata. Aktivitas rekreasi merupakan pelengkap dari kerja, oleh karena itu rekreasi adalah kebutuhan semua orang. Dengan demikian, penekanan dari aktivitas rekreasi adalah dalam nuansa "menciptakan kembali" (recreation) orang tersebut, ada upaya revitalisasi jiwa dan tubuh yang terwujud karena 'menjauh' dari kegiatan rutin dan kondisi yang menekan dalam kehidupan sehari-hari.

Rekreasi telah menjadi unsur penting dalam kehidupan masyarakat modern. Berkembangnya jaman, padatnya aktivitas dan tingginya tuntutan hidup serta tingkat stres membuat kebutuhan masyarakat akan rekreasi dan hiburan semakin meningkat. Dewasa ini, perubahan perilaku dan cara pandang masyarakat mendorong kegiatan berekreasi tidak lagi sekedar dianggap sebagai pemenuhan kebutuhan semata, tetapi sudah menjadi bagian dari life style atau gaya hidup.

Motif pergi rekreasi dan jalan-jalan juga dialami oleh para wisatawan yang mengunjungi Masjid Agung Madani Islamic Centre (MAMIC). Berdasarkan hasil wawancara mereka menyatakan bahwa motif kunjungan mereka ke MAMIC adalah untuk berekresi guna untuk istirahat sejenak dari rutinitas sehari-hari.

\section{Melihat Desain dan Arsitektur Masjid}

Pada awalnya bangunan masjid muncul sebagai bangunan religi yang merupakan hasil perpaduan antara fungsi bangunan sebagai unsur arsitektur islam yang perpedoman pada ketentuan-ketentuan yang ada pada syari'at islam dengan bangunan sebagai pengungkapan nilai tertinggi yang diwijudkan dalam bentuk bangunan. ${ }^{3}$

Arsitektur masjid telah mengalami prerkembangan yang sangat komplek dikarenakan kecenderungan memasukkan budaya daerah yang ada. Banyak pula arsitektur masjid selain tetap ada unsur utama masjid, juga mengadopsi gaya arsitektur Timur Tengah, India, dan lain-lain.

Berdasarkan pemaparan hasil wawancara peneliti dengan informan dapat diambil kesimpulan bahwa yang menjadi motif mereka mengunjungi MAMIC adalah untuk melihat desain dan arsitektur masjid yang menyerupai masjid nabawi. Atas dasar keingin tahuan untuk melihat masjid inilah yang mendorong para wisatawan mengunjungi MAMIC.

\section{Dorongan ataupun ajakan Dari Teman}

Salah satu faktor yang membuat para wisatawan berkunjung ke Masjid Agung Madani Islamic Centre adalah teman. Teman merupakan seseorang orang yang dekat dengan kita dan biasanya juga memiliki cukup andil besar dalam mengambil keputusan tempat tujuan ataupun tempat rekreasi. Atas masukan dan saran dari teman lah biasanya kia mengambil keputusan mengenai tempat tujuan rekreasi.

Berdasarkan pemaparan hasil wawancara penulis dengan informan dapat diambil kesimpulan bahwa yang menjadi motif mereka berkunjung ke MAMIC adalah karena adanya dorongan ataupun ajakan dari teman.

\footnotetext{
${ }^{3}$ Wiryoprawiro, Perkembangan Arsitektur Masjid di Jawa Timur, hal 155
} 


\section{Melihat Iklan ataupun Pamflet}

Iklan juga memiliki andil dan juga mempengaruhi sesorang untuk mengunjugi suatu destinasi. Semakin bagus iklan dan pamflet yang tersebar semakin banyak pula pengunjung yang datang ke MAMIC.

Berdasarkan hasil wawancara penulis dengan informan dapat disimpulkan bahwa yang mempengaruhi perjalanan wisatawan karena melihat iklan ataupun spanduk di jalanan yang menimbulkan ketertarikan tersendiri pada orang yang melihat iklan ataupun spanduk tersebut yang pada akhirnya mereka memiliki keinginan untuk mengunjungi Masjid Agung Madani Islamic Centre.

\section{Dapat Informasi dari Internet dan Media Sosial}

Pada zaman era digital sekarang ini informasi apapun begitu mudah didapatkan dari media sosial, tidak terkecuali informasi mengenai Masjid Agung Madani Islamic Centre. Berkat adanya media sosial pengunjung pun berdatangan ke MAMIC tidak hanya orangorang dari rokan hulu, luar provinsi Riau bahkan ada pengunjung dari luar Indonesia. Disini dapat kita lihat bahwa televisi dan media sosial sangat berperan aktif dalam menyebarkan informasi secara cepat. Salah satu acara televisi yang menayangkan mengenai keindahan MAMIC diantaranya yaitu My Trip My Adventure dan Makan bersama yang ditayangkan di Trans TV.

\section{Penutup}

Berdasarkan hasil temuan pada BAB III, motif wisatawan mengunjungi masjid agung madani islamic centre ini dikelompokkan menjadi lima, yaitu: (1) pergi berwisata dan jalanjalan (2) Melihat desain ataupun arsitektur masjid. Kedua temuan tersebut berkaitan dengan motif in order to motive yang dikemukakan oleh Alfred Schutz. Selain itu juga ditemukan motif yang disebabkan oleh (1)Informasi ataupun dorongan dari teman (2) Melihat iklan dan spanduk (3) Informasi dari Internet dan media massa. Ketiga temuan tersebut bekaitan dengan faktor yang berada diluar diri individu tersebut (because order to motive).

Setelah dilakukan analisis terhadap hasil wawancara maka peneliti dapat mengambil kesimpulan bahwa yang menjadi motif dominan adalah motif fisik. Dimana motif ini sangat berkaitan dengan usaha seseorang untuk mengembalikan kondisi fisik, beristirahat dari aktivitas yang melelahkan, bersantai, berolah raga, atau pemeliharaan kesehatan agar kegairahan bekerja dapat timbul kembali.

Berkaca dari keterbatasan kesempatan dan waktu waktu pada penelitian ini, kepada peneliti selanjutnya yang tertarik meneliti mengenai pokok persoalan yang serupa diharapkan dapat meneliti mengenai dampak dari kunjungan wisatawan ke Masjid Agung Madani Islamic Centre.

\section{Daftar Pustaka}

Suherman, Eman. (2012). Manajemen Masjid: Kiat Sukses Meningkatkan kualitas Sumber Daya Manusia melalui Optimalisasi Kegiatan Umat Berbasis Pendidikan Berkualitas Unggul. Bandung: CV. Alfabeta.

Sumadi Suryabrata. (2012). Psikologi Pendidikan. Jakarta: Rajawali Pers

Wiryoprawiro.(2012). Perkembangan Arsitektur Masjid di Jawa Timur, hal 155 